\title{
GIROLAMO ZANCHI ON UNION WITH CHRIST AND THE FINAL JUDGMENT
}

\author{
J.V. FESKO* \\ Reformed Theological Seminary
}

\begin{abstract}
Union with Christ was a key doctrine for second-generation Reformed theologian Girolamo Zanchi. As a Thomist, Zanchi shared similar elements with Thomas Aquinas in his understanding of salvation as participatio, but his understanding of union with Christ differed with regard to the difference between infused and imputed righteousness. Unlike Aquinas's doctrine of infused righteousness, Zanchi argued for imputed righteousness, which was both the foundation for one's justification in this life as well as appearing before the divine bar at the final judgment. Zanchi's doctrine of union with Christ has the utmost significance for personal eschatology and the judgment believers undergo at the great assize, insights that are worth retrieving for a clear understanding of the relationship between justification and the final judgement.
\end{abstract}

KEYWORDS: Union with Christ, participation (participatio), insitio Christi, imputed righteousness, infused righteousness, Aquinas, Zanchi, final judgment

\section{Introduction}

The doctrine of participatio or union with Christ has been a prominent theme in historical and doctrinal literature. Some have claimed that union with Christ is a panacea for healing the doctrinal rift between the Western and Eastern churches (Braaten and Jenson 1998: vii-ix). Others have claimed that union is the great insight of John Calvin (1509-64) and that later Reformed theologians ignored or abandoned his doctrine (Partee 2008: 13-35). Calvin's successors traded their doctrinal inheritance for a bowl of scholastic lentils when they supposedly moved away from union and embraced the ordo salutis (Evans 2008: 40, 264-67). And still others claim that if the church can only recapture Calvin's doctrine of union with Christ it can fix all that is wrong with evangelical theology (Johnson 2013: 25-27). As important as union with Christ is, a number of these claims fail adequately to examine the underlying development of the doctrine, albeit with some notable exceptions (e.g., Muller 2012: 202-43, 277-85). This essay repreical Theology at Reformed Theological Seminary, Jackson, MS. Email: jfesko@rts.edu. 
sents the effort to trace historically the use of the doctrine of union with Christ in the writings of one second generation Reformed theologian, Girolamo Zanchi (1516-90). But why choose Zanchi? And of what relevance is his doctrine of union with Christ to eschatology?

Zanchi is an excellent choice to explore for several reasons. First, as a second-generation reformer he was well acquainted with theologians, such as Calvin and Peter Martyr Vermigli (1500-62), and Reformed doctrine. Zanchi, for example, prepared a compendium of Calvin's 1543/5 Institutes, a key Reformation theology text (Muller 1988: 111). In fact, Zanchi studied with Calvin for ten months in Geneva (Donnelly 1976: 88). Second, Zanchi wrote a doctrinal locus specifically on union with Christ, which originated in his commentary on Ephesians (Zanchi 1592). In addition to this work, he also penned a confession of faith, De Religione Christiana Fides, which was originally intended to replace Zurich's Second Helvetic Confession (Zanchi 2007: I.14-16). The doctrine of union with Christ features prominently throughout his confession and thus showcases how it functioned in his broader theology. Both documents open a window into how the doctrine of union with Christ intersected with Zanchi's eschatology, specifically the nature of God's evaluation of the believer's good works at the final judgment.

This essay defends the idea that Zanchi promoted a Thomist doctrine of participatio with a key difference, namely, he argued for imputed rather than infused righteousness in his doctrine of justification. As a theologian trained in Thomism, Zanchi naturally echoed a number of Thomist themes in his doctrine of union with Christ, but his commitment to imputed righteousness altered the overall structure of his doctrine of justification. Rather than posit a linear and sequential process of justification as in the theology of Thomas Aquinas (1225-74), where justification is not completed until the final judgment, Zanchi presents a different idea. For Zanchi, the verdict of the final judgment enters the present and secures the believer's right to eternal life the moment she professes her faith. The realized eschatology of Zanchi's doctrine of justification impacts the nature of God's evaluation of the believer's good works at the final judgment.

To prove these claims, this essay proceeds in three stages. First, it examines Aquinas's doctrine of participatio, or union with Christ, to establish a baseline for comparison with Zanchi. Second, the essay explores Zanchi's doctrine of union with Christ and the related issues of justification, sanctification, and eschatology. Third, in the effort to strive for more than good historiography, the essay offers some brief reflections on the importance of Zanchi's contribution to the development of the doctrine of union with Christ. In particular, this theological archaeology facilitates the retrieval of several emphases in Zanchi's doctrine of union with Christ in order to transcend some of the present shortcomings of contemporary theology as it 
concerns the relationship between union with Christ and eschatology (Webster 2007: 589). In the words of C. S. Lewis (1898-1963), we can let the fresh breeze of ages past blow through our minds to remind us of forgotten truths (Lewis 1970: 202). In this case, Zanchi reminds us of the importance of never letting union with Christ drift to the background when considering how God evaluates believers' good works at the final judgment. The essay concludes with summary observations about Zanchi's doctrine of union with Christ and eschatology.

\section{Thomas Aquinas}

Aquinas is best known for his monumental Summa Theologica, a work that became the gold standard for systematic presentations of doctrine for centuries to come. What might not be known, however, is that union with the triune God was one of the key themes of his Summa. In the overall scope of Thomas's work, the various subdivisions rotate around the axis of union with God. Thomas explains, for example, in the first part of his Summa that when God created all things, and in particular, humankind, he designed them to seek him and his goodness as the end of all things. The pursuit of God's goodness, however, was not merely a pilgrimage to obtain an abstract ideal, but rather to desire God himself and to participate in his being by virtue of bearing his image (Aquinas 1948: Ia q. 44 art. 4; cf. Canlis 2010: 38-39; Williams 1997: 53-74; Spezzano 2015). Thus God creates humans in his image, which manifests their participation in God, and gives to them the goal of returning to God-this is the divine side of the coin, with respect to the act of creation.

In the second part of the Summa, Aquinas treats the flip side of the coin, namely humanity's return to God via union with him. Thomas presents union with God as the chief purpose of creation. In a sinless world, humans were capable of this return to God, but this is not the case in a sin-fallen world. The entrance of sin necessitates the intervention of the mediator and the incarnation. The incarnation, according to Thomas, establishes a union between God and humanity generally in the hypostatic union of the two natures of Christ. Aquinas writes: 'The full participation of the Divinity, which is the true bliss of man and end of human life; and this is bestowed upon us by Christ's humanity; for Augustine says in a sermon (xiii, de Temp.): 'God was made man, that man might be made God' (Aquinas 1948: IIIa q. 1 art. 2). Here Thomas favorably cites Augustine (354-430) on the nexus that exists between Christ's union with humans through the incarnation and the redeemed sinner's union with God through Christ in his redemption (Porter 2005: 187).

So, for Aquinas, soteriology as a whole is union with Christ, but how does he explain the various elements of the believer's union with Christ? 
What is the relationship between justification and sanctification? Aquinas did not distinguish between justification and sanctification. For Aquinas, justification is a process by which redeemed sinners grow in their sanctification: 'The justification of the ungodly', writes Aquinas, 'is a certain movement whereby the human mind is moved by God from the state of sin to the state of justice' (Aquinas 1948: Ia IIae q. 113 art. 5). How does the sinner move from a state of sin to one of righteousness? For Aquinas, this movement (or process) comes through the infusion of grace (Aquinas 1948: Ia IIae q. 113 art. 6). One can summarize Aquinas's understanding of justification as a four-stage process:

1. The infusion of grace;

2. The movement of the free will directed towards God through faith;

3. The movement of the free will directed against sin;

4. The remission of sin (McGrath 2005: 64; cf. Aquinas 1948: Ia IIae art. 8).

Given that justification is a process, this means that the believer's just status hinges upon his sanctification. Aquinas carries this point through his soteriology by his understanding of faith, which is formed by love: 'Now faith works through charity. The love of charity therefore is the form of faith' (Aquinas 1974: IIa IIae q. 4 art. 3). Or to use technical terms, fides charitate formata (cf. Lombard 2007: III.xxiii.3).

This is not to say, however, that God's grace was unnecessary in the process of justification. On the contrary, Aquinas believed that the grace of God was vital. But Aquinas did not let the theme of union with the triune God drop out of view in his doctrine of justification. Rather, Aquinas explains:

The gift of grace surpasses every capability of created nature, since it is nothing short of a partaking of the Divine Nature, which exceeds every other nature. And thus it is impossible that any creature should cause grace. For it is as necessary that God alone should deify, bestowing a partaking of the Divine Nature by a participated likeness as, it is impossible that anything save fire should enkindle (Aquinas 1948: Ia IIae q. 112 art. 1).

There are two things to note about this statement. First, Aquinas coordinates the infusion of grace with union (or participation); he coordinates the bestowal of grace with his exegesis of 2 Peter 1:4. Second, when Aquinas writes of infused grace, he has in mind the infusion of habits, or virtue. It is through these infused habits that the Spirit enables Christians to pursue the imitatio Christi, which leads to the completion of their justification. In his lectures on the Gospel of Matthew, specifically Matthew 24:47, Aquinas explains that a blessing of the imitation of Christ is union with him: 'In this 
world, we do not reach perfection except by following the footsteps of Christ, just as, in the other world, eternal happiness is only obtained through union with Christ' (Torrell 2003: II.368). Hence, for Aquinas, the believer's growth and ultimate justification hinges upon his sanctification, but this is a process that he wraps in union with Christ. In a word, for Aquinas, Christ is both the road and the goal of the believer's redemption (Torrell 2003: II.368).

\section{Zanchi on Union and Eschatology Union with Christ}

Zanchi's doctrine of union with Christ bears a number of similarities to Aquinas's, though there are some discontinuities. Like Aquinas, Zanchi stretches his doctrine of union from creation to consummation. He contends that there is a threefold union with Christ: (1) one made with our nature, (2) one that operates on a daily basis, and (3) when God perfectly conforms the redeemed to the image of God in their glorification. The first union refers to the incarnation of Christ, when the Logos assumed a human nature. God accomplishes the second through the Holy Spirit and the application of redemption-by mystical union with Christ. Like Thomas, Zanchi appeals to Peter's statement about participation in the divine nature (2 Pet. 1:4). The third and final union occurs at the consummation when God assumes believers into everlasting glory with Christ. This threefold pattern bears a noticeable resemblance to the views of Aquinas, especially when Zanchi describes this threefold union as sicut natura ordinata est ad gratiam et gratia ad gloriam ('nature ordained to grace and grace to glory'), which echoes Thomas's threefold understand of nature, grace, and glory (Zanchi 2007: XII.v, II.235).

Note, for example, what Aquinas states about the three stages of the image of God:

We see that the image of God is in man in three ways. First, inasmuch as man possesses a natural aptitude for understanding and loving God; and this aptitude consists in the very nature of the mind, which is common to all men. Secondly, inasmuch as man actually or habitually knows and loves God, though imperfectly; and this image consists in the conformity of grace. Thirdly, inasmuch as man knows and loves God perfectly; and this image consists in the likeness of glory. Wherefore the words, 'The light of thy countenance, O Lord, is signed upon us' (Ps. 4:7), the gloss distinguishes a threefold image of creation, of re-creation, and of likeness. The first is found in all men, the second only in the just, the third only in the blessed (Aquinas 1948: Ia q. 93 art. 4; Spezzano 2015: 76-77).

When we coordinate the three stages of the image of God with the application of the work of redemption, each the stage corresponds to the respec- 
tive works of Christ and the Spirit. Christ as the image of God redeems sinners and the Spirit applies his work to facilitate their ultimate conformity to God. In fact, Aquinas introduces Ia q. 93 with the statement: 'We now treat of the end or term of man's production, inasmuch as he is said to be made to the image and likeness of God' (Aquinas 1948: Ia q. 93). This goal is what one historian calls deiformitas (Spezzano 2015: 78). Like Aquinas, Zanchi appeals to 2 Peter 1:4 to support his doctrine of union with Christ (cf. Aquinas 1948: Ia IIae q. 112 art. 1; Spezzano 2015: 15). These similarities challenge the popular claim that Calvin introduced the doctrine of union with Christ to the Reformed tradition and subsequent so-called Calvinists gleaned or distorted the doctrine in agreement or disagreement with the Genevan reformer (e.g., Partee 2008: 13-35, 40-41). Given Zanchi's Thomist training, the more likely scenario is that he gleaned the concept from Aquinas.

\section{Justification and sanctification}

But even with the continuities, there are discontinuities as it relates to infused versus imputed righteousness (Fesko 2012: 221-24). Zanchi explains that those whom the Spirit regenerates receive faith in Christ, the remission of sins, and the righteousness of Christ. When God looks upon the sinner, he only sees the righteousness of Christ because the Spirit has engrafted the sinner to him (Zanchi 2007: XIX.i, I.334-35). In a word, sinners are justified and declared righteous because they are united to Christ. But Zanchi explains and distinguishes how sinners are justified. Zanchi believes that a person receives both imputed and inherent righteousness through union with Christ: 'We believe also that he who through Christ, into whom he is engrafted by the Holy Spirit, is accounted righteous, and is truly righteous, having obtained forgiveness of his sins in Christ, and imputation of his righteousness' (Zanchi 2007: XIX.ii, I.334-37; note updated translations in all subsequent Zanchi quotations). Zanchi goes on to write, 'The same man forthwith is possessed of the gift of inherent righteousness, so that he is not only perfectly and fully righteous in Christ his head, but has also in himself true righteousness, whereby he is indeed made conformable unto Christ' (Zanchi 2007: XIX.ii, I.334-37).

While sinners receive both imputed and inherent righteousness through union with Christ, Zanchi stipulates first that the doctrine of justification by faith alone involves the remission of sins and imputation of the righteousness of Jesus Christ (Zanchi 2007: XIX.ii, I.336-37; Farthing 1993: 642). In other words, justification is purely forensic in nature. It does not change a person's being, only her state-it is not transformative or renovative as with sanctification, which stands in contrast to Aquinas's view. Second, the sinners' status coram Deo always rests upon her justification rather than her sanctification: 'We confess that this inherent righteousness is through our 
own fault so imperfect in us, that we are made righteous before God, and can be accounted righteous only by that righteousness of Christ, whereby our sins are not imputed, not only in the beginning of our conversion, when of wicked we are made godly, but even after to the end of our lives' (Zanchi 2007: XIX.iii, I.338-39). This brings two important concomitants.

First, Zanchi emphasizes that justification is by faith alone and is not based on the believer's good works: 'A man is justified by that righteousness which consists in the forgiveness of sins and imputation of Christ's righteousness, and not properly of his own works, but by them he is declared to be justified and to be righteous' (Zanchi 2007: XIX.xi, I.336-47). Second, in both his confession as well as in his locus on union, Zanchi states that sanctification is the effect of justification (Zanchi 2007: XIX.v, I.340-41; idem 1592: 134; idem II.378). Zanchi did not believe that justification is the efficient cause of sanctification, which would compromise its forensic character; rather, in terms of Aristotelian metaphysical distinctions common to early modern Reformed theology, this is a common way to express both the priority of justification to sanctification and maintain their inseparability (Farthing 1993: 643). Unlike Enlightenment models, sixteenth-century theology knows of no effects without causes. Zanchi expresses the inseparability of justification and sanctification not only with the metaphysical distinction of cause and effect, but also through an analogy perhaps gleaned from Calvin (cf. Calvin 1948: III.xi.6). Concerning imputed and imparted righteousness, Zanchi writes: 'These two means of communicating other good things, and especially the justice and righteousness of Christ, are so joined and linked together in themselves, as it were the cause and the effect, that they are not severed asunder, nor ought to be severed by us, no more than the sun beam can be severed from the sun, or the sun from the beam' (Zanchi 1592: 134; idem 1888: II.378).

Questions naturally arise as to why Zanchi gives justification (or the forensic) priority over sanctification. For Zanchi, both justification and sanctification are benefits of the believer's union with Christ. The priority that Zanchi assigns to justification is logical, not temporal or chronological. Does the answer lie in the theological debates between the Roman Catholic Church and the Reformed? In one sense, these debates provide a partial answer to the question. However, for Zanchi and other reformers, it was not simply a question of swinging the pendulum as far as possible in the opposite direction from infused righteousness and justification by faith and works. While other reformers might provide slightly different answers, for Zanchi at least, the priority of the forensic lay in the creation and the fall of Adam.

In Zanchi's defense of imputation, he appeals to Romans 5:19, 'So by the one man's obedience the many will be made righteous'. Zanchi believes that 
the parallel between Adam and Christ establishes the priority of the forensic. In an extended explanation, Zanchi establishes the parallel between the two Adams:

\begin{abstract}
We must firmly hold this foundation, which we have laid before: that as the apostle makes two Adams, the first and the second, the earthly and heavenly, as it were two heads and principles of mankind, one after the flesh, another after the spirit: so also even out of that history of Moses, he gathers and sets down to us, that there is a double marriage, the first and the second, a carnal and a spiritual marriage, the one simply for the creating and multiplying of men in this world, the other for the replenishing and filling of the kingdom of heaven with the sons of God (Zanchi 1592: 30; idem 1888: III.342-43).
\end{abstract}

All of those naturally united to Adam receive his imputed guilt and all of those united to Christ receive both his active and passive obedience through imputation: 'For both parts of that obedience, which was really performed by Christ, is communicated to us by imputation, and is truly made ours by the right of marriage, seeing the whole Christ, how great so ever he is, is made one flesh with us, and we likewise with him' (Zanchi 1592: 136-67; idem 1888: III.378).

Zanchi states that the mystical is grounded upon the forensic, for apart from the forensic there is no mystical union. He goes as far as to say that justification by faith alone yields eternal life, for just as Adam's one sin brings eternal death, so too Christ's one act of righteousness brings eternal life (Zanchi 1592: 138-39; idem 1888: II.379; idem 2007: XII.i, I.230-31). In a word, given that marriage is a key to understanding union with Christ, Zanchi believes that because of what Paul writes in Ephesians 5:22-33, the creation account of Adam and his marriage to Eve must be read christologically (Farthing 1993: 625). For Zanchi, therefore, establishing the doctrine of union with Christ is not merely a question of ontology —of deciding whether justification and sanctification have a more fundamental ontological source-but ultimately one of relating soteriology to redemptive history.

\title{
Union and eschatology
}

The relationship between justification and sanctification is not just about soteriology; it has implications for Zanchi's understanding of the relationship between union and eschatology, which further distinguishes his formulation from Aquinas's. Both Thomas and Zanchi extend union with Christ into their doctrines of eschatology. In Aquinas's formulation, the one united to Christ strives for the status of righteous through the indwelling grace of the Spirit, by faith working through love (Aquinas 1974: IIa IIae q. 4 art. 3). In the event that the redeemed sinner commits mortal sin, she loses her justified status (Raith II 2014: 164). Or, in the event that she dies before she 
attains a sufficient degree of righteousness, she must first go to purgatory before paradise (Aquinas 1948: Appendix II, arts. 1-2). The sinner's eschatological state hinges, therefore, on the degree to which she meets the demands of holiness through her sanctification, or the on-going process of justification. God does not declare a sinner righteous until she actually is righteous. This is the nature of how infused righteousness functions within Aquinas's doctrine of union with Christ.

By way of contrast, imputed righteousness functions differently in Zanchi's doctrine of union. There is no soteriological uncertainty-the justified sinner has right and title to eternal life the moment she professes her faith in Christ. There is no shadow of mortal sin or purgatory that hangs over the sinner's head. Instead of the believer providing her own graceempowered righteousness to stand before the divine bar, Zanchi argues that believers possess Christ's righteousness by imputation. Imputed righteousness produces three consequences for Zanchi's eschatology: (1) inaugurated eschatology versus the linear eschatology of Thomas, (2) union with Christ never recedes to the background as it does with Thomas, and (3) the foundation of imputed righteousness conveys hope for afflicted believers.

First, imputed righteousness creates a different eschatological structure for Zanchi in comparison with Thomas. For Aquinas, the redeemed sinner must acquire a sufficient degree of righteousness in order to warrant the divine verdict of righteous at the final judgment. For Thomas, eschatology is linear and sequential. Justification awaits the eschatological judgment in the future, and it does not occur a moment sooner given the possibility of losing one's justified status and the looming prospects of purgatory for the one who fails to meet the divine standard. For Zanchi, on the other hand, the eschatological verdict enters into the present. The sinner's right to eternal life rests on the imputed perfect righteousness of Christ. Zanchi writes that the redeemed sinner is persuaded that the perfect righteousness of Christ is so imputed unto him, that he knows eternal life to be even due unto him for the same in like sort as it is due to Christ' (Zanchi 2007: XIX.iv, I.33839). In Zanchi's view, the present age overlaps with the eschaton given that the verdict of the final judgment appears in the middle of history in the justification of fallen but redeemed sinners, those who are united to Christ (Hampson 2004: 9-55). The inaugurated eschaton surfaces in Zanchi's soteriology because he rejects the doctrine of purgatory. Rather than posit an intermediate destination for those who fail to meet the standard of holiness, Zanchi argues that when believers die, their souls neither sleep nor 'lie still in some close place both out of heaven and hell, nor yet are tormented in purgatory, but that out of the body also men's souls do live, understand and desire; and that the souls of the godly do reign with Christ in heaven'. Con- 
versely, the souls of the ungodly suffer the torments of hell (Zanchi 2007: XXVIII.i, I.500-03).

Second, union with Christ never recedes into the background as it does with Thomas's doctrine. Thomas incontestably founds his doctrine of union on the grace of God, and his understanding of merit reflects this commitment. When believers perform good works, God does not asses their worth in terms of strict justice. Rather, God only evaluates their good works on the basis grace. In a sense, believers can condignly merit eternal life because they participate in the divine nature (Spezzano 2015: 147). According to Thomas, the Holy Spirit moves believers 'to eternal life according to John $4: 14$, 'It shall become in him a fount of water springing up to eternal life'. And the worth of the work depends on the dignity of grace, by which man, made a sharer of the divine nature, is adopted as a son of God, to whom the inheritance is due by right of adoption, according to Romans 8:17, 'If sons, then heirs also' (Aquinas 1948: IIIa q. 114 art. 3). They can merit eternal life because they participate in the divine nature-they are in union with Christ. Christ certainly undergirds the salvation of the believer, but the believer nevertheless contributes to her salvation through her good works. In this structure, Christ is present but nevertheless recedes to the background. Such a picture differs from Zanchi's configuration.

Recall that believers already possess right and title to eternal life by virtue of their justification, which rests on the imputed active and passive obedience of Christ. This point emerges in two ways: justification is by faith alone and the manner by which God evaluates the believer's good works at the final judgment. Zanchi defended the idea that, even for redeemed sinners in union with Christ, their Spirit-empowered good works were nevertheless stained by sin. We receive inherent righteousness through union with Christ but it is imperfect, whether at the beginning or end of the Christian life (Zanchi 2007: XIX.iii, I.338-39). This is why justification can never rest on the believer's inherent righteousness or good works. On this note, Zanchi writes: 'Whatsoever inherent righteousness there is in us and whatsoever good work we do, is such as cannot stand in the sight of God. According to the saying: 'Enter not into judgment with your servant, oh Lord, for no flesh is righteous in your sight' (Psa. 142:2) and that also: 'If you mark iniquities, oh Lord, Lord who can stand' (Psa. 130:3)' (Zanchi 2007: XIX.vii, I.342-43)? Whether at the beginning of conversion or at the end of life, God justifies the believer by faith alone, and never by her good works (Zanchi 2007: XIX.viii, I.344-45).

In terms of believers and the great assize, Zanchi, unlike Thomas, keeps Christ front and center. To highlight its status as the 'free gift of God', Zanchi reminds his readers that Christ purchased salvation entirely by his merits alone, and as such, it is a 'free reward'. Even the believer's good works, 
'and all the causes, wherefrom the same do proceed, are free gifts of God: free election, free redemption, free calling, faith, justification, regeneration, forgiveness of sins and lastly a free pardon of all wants and imperfections, wherewith our good works are infected, and a free imputation of Christ's perfect obedience, wherewith our imperfect obedience is clothed and made acceptable to God' (Zanchi 2007: XXIX.v, I.514-15). Unlike Aquinas, who argues that believers merit eternal life through their union-fueled good works, Zanchi instead argues that God does indeed evaluate our good works but he nevertheless recognizes they are still imperfect. This means that God does not evaluate them in terms of justice but rather mercy. Moreover, Christ still stands prominently front and center because God clothes the believer's good works in the robe of Christ's imputed righteousness: 'And consequently, to speak properly, is a reward not due unto us for our own works considered in themselves, but for the merits of Christ imputed to us' (Zanchi 2007: XXIX.v, I.514-15). Both Thomas and Zanchi posit the evaluation of the believer's good works at the final judgment, but for Thomas these good works complete justification. For Zanchi, however, Christ's imputed righteousness has already completed the believer's justification at the moment of her profession of faith. Her good works confirm her justified status, but they do not contribute to or complete it (Zanchi 2007 XIX.xi, I.346-49).

Third, imputed righteousness is a sure foundation for the believer's hope in the face of trials and tribulation. The believer lives from the future, not the present. In contrast to Roman Catholic views of union with Christ, where the believer can fall out of union through mortal sin, Zanchi believes that union with Christ is a great source of hope for the Christian (Farthing 1994: 332-54). This is where the third aspect of Zanchi's threefold doctrine of union with Christ comes to the fore-the assumption of believers into everlasting glory. Union with Christ was a great source of hope because believers were immutably elected into union with Christ. However, beyond this, in the midst of life's struggles and trials, Zanchi also notes the blessings and hope that believers have through union with Christ as they await the consummation of the age. The believer can know that because of Christ's imputed righteousness received through faith in justification, 'eternal life is as due unto him as it was to Christ, and consequently finds the same to be due to free grace and favor and not for his own works' (Zanchi 2007: XIX.iv, I.338-39). Hence, the believer rests assured that eternal life has been indefectibly secured by Christ's works, not her own. Furthermore, those who are united to Christ share in his resurrection from the dead (Zanchi 1592: 114; idem 1888: III.371). Christ ultimately and finally restores what was lost in Adam. Zanchi bases this conclusion on two points: 'First, because that right and dominion which was given to Adam over the 
rest of the creatures before his fall, is in Christ our husband and head restored to us, who are made one flesh with him'. Zanchi gives the second point, 'Because in the same Christ we have not only a right over all these things, but we have also a perfect and full possession of all things'. How and why does Zanchi draw these conclusions? Because Christ has ascended to the right hand of the Father and the elect in him sit in the heavenly places with Christ. Zanchi concludes: 'Therefore if the husband is Lord of this inferior world, the wife must also be lady and mistress of the same' (Zanchi 1592: 130; idem 1888: II.376). John Farthing cogently summarizes Zanchi's understanding of eschatology and union when he states: 'Underlying the points of vital contact that unite Zanchi's Christology, ecclesiology, eschatology, and spirituality is a profound and almost mystical doctrine of union with Christ' (Farthing 1994: 341).

\section{The Case for Retrieval}

Zanchi's doctrines of union and eschatology offer important emphases that warrant retrieval. In evangelical circles there are some who claim allegiance to the Reformed faith. They tout the doctrine of union with Christ, which supposedly is a cardinal insight of the Reformation, but at the same time reject the doctrine of imputation. In recent debates over justification $\mathrm{N}$. T. Wright, for example, posits a two-staged justification all the while professing his commitment to the Reformed faith. There are many facets to this debate that this brief section cannot cover, but we can offer a comparative reflection between Wright's and Zanchi's claims regarding union with Christ and the final judgment. This section thus first briefly sets forth Wright's claims and then compares them with Zanchi's doctrine.

Wright divides justification into two stages, what he calls present justification, which is pronounced over faith alone, and final justification, which will be pronounced over the totality of the believer's life. Wright stipulates that God's judgment will be 'in accordance with 'works', with the life seen as a whole-not that any such life will be perfect (Phil 3:13-14)' (Wright 2011: 60; cf. idem 2013: 936-47). Although, elsewhere Wright states: 'This just judgment... will be on the basis of the totality of the life that has been led. God will 'repay' to each according to their works' (Wright 2013: 938). Wright bases his claim on Romans 2:13, 'It is not the hearers of the law who are righteous before God, but the doers of the law who will be justified', among other texts as exegetical reason to conclude that the apostle Paul teaches a future justification: 'For Paul, future justification will be in accordance with the life that has been lived' (Wright 2011: 61). Wright agrees with recent analysis that claims that union with Christ and adoption are key categories that might reconcile Wright's views (a new perspective) with the socalled 'old perspective on Paul' (Wright 2011: 62; cf. Vanhoozer 2011: 235- 
58). So, in line with classic Reformed theology, Wright affirms the doctrine of union with Christ. But at the same time, affirming such a doctrine is not uniquely Reformed but rather part of the catholic tradition, undeniably evident in Aquinas's doctrine of participatio. Where Wright specifically demurs against Reformed theology is on the doctrine of imputed righteousness (e.g., Wright 2007: 63; idem 2013: 946-47, 949-51). Wright rejects imputed righteousness because it supposedly has its origins in medieval views of righteousness, which maintains the idea that righteousness is something that can be shared or passed to and fro (Wright 2013: 947).

There are five points of comparison to make in view of Wright's claims. First, there are some significant similarities between Wright and Aquinas. Both affirm a doctrine of union with Christ and a final judgment that evaluates the believer's good works to finalize justification. In fact, both Aquinas and Wright offer similar explanations of Romans 2:13 (cf. Aquinas 2012: 74; Wright 2002: 440). Concerning Romans 2:13 Wright succinctly states: 'Justification, at the last, will be on the basis of performance, not possession [of the Torah]' (Wright 2002: 440). Second, like Aquinas, Wright indisputably rests his doctrine of salvation on the work of Christ applied by the Spirit (e.g., Wright 2013: 939-40). Third, both do not appeal to the concept of imputed righteousness, though this is arguably an anachronism for Aquinas given the relative absence of the doctrine in the middle ages. Fourth, a point of discontinuity between the two theologians is that, for Aquinas, one can lose her justified status due to the commission of mortal sin, or go to purgatory if she has an insufficient degree of righteousness. Wright claims that present justification is indefectible, and he rejects the doctrine of purgatory as mythology (Wright 2011: 62; idem 2008: 166-71).

That being said, the fifth point of comparison, and for the purposes of this essay the most important is, as with Aquinas, Christ drifts to the background when the believer stands for the final judgment and his final justification. Wright for example states: 'Present justification is utterly dependent on the past achievement of the cross' (Wright 2013: 950). Whereas future justification rests mostly on the work of the Spirit (Wright 2013: 940). Wright gives a fuller explanation that showcases the shift from Christ to the Spirit in the transition from present to future justification:

Paul's vision in Romans 1-8, then, has as its framework the all-important narrative about a future judgment according to the fullness of the life that has been led, emphasizing the fact that those 'in Christ' will face 'no condemnation' on that final day (2.1-16; 8.1-11, 31-39). The reason Paul gives for this is, as so often, the cross and the spirit $[s i c](8.3-4)$ : in the Messiah, and by the spirit [sic], the life in question will have been the life of spirit-led [sic] obedience, adoption, suffering, prayer and ultimately glory (8.5-8, 12-17, 18-27, 28-30) (Wright 2013: 941). 
Christ constitutes the foundation for the believer's salvation, but the believer nevertheless has to complete her justification because final justification rests on the totality of the life lived; the judgment is on the basis of the Spirit-produced works. Wright's understanding of the final judgment differs from Zanchi's and aligns more closely with Aquinas's formulation. For Zanchi, God evaluates the believer's good works but they are not constitutive of her justification and Christ's imputed righteousness blankets the good works to hide their imperfections.

As with Aquinas, a significant difference between Zanchi and Wright revolves around the question of imputed righteousness. There is insufficient space exegetically and theologically to weigh the pros and cons of imputed righteousness, but this is where the question of theological retrieval enters the picture. Wright does not demonstrate that he has an accurate account of either the origins or the nature of the Reformed doctrine of imputed righteousness. This means that, at a minimum, investigating the doctrine, especially as it pertains to advocates like Aquinas and Zanchi, would be the better part of prudence. Rather than merely appeal to contemporary explanations of Reformed soteriology as Wright does, why not pull out a few chairs so historic witnesses like Zanchi and Aquinas can have seats at the table. By opening the conversation to include other voices, Wright and others can benefit from the fresh breeze of the centuries to help us better understand questions such as the relationship between union with Christ and the final judgment.

\section{Conclusion}

This brief survey of Aquinas and Zanchi reveals that there is much work to be done with regard to the doctrine of union with Christ. Far from a soteriological category, union with Christ extends from creation to consummation in the theologies of Aquinas and Zanchi. Zanchi's own doctrine does not originate from the soil of Geneva and the theology of Calvin but has deeper roots in the catholic tradition and the theology of Thomas Aquinas. That being said, whatever similarities that exist between Aquinas and Zanchi does not minimize important differences, most notably infused versus imputed righteousness. The difference in their respective doctrines of justification and the roles of infused versus imputed righteousness is significant, especially as it relates to the final judgment and the evaluation of the believer's good works. Are good works constitutive of justification and thus complete it or do they confirm the believer's already-completed justified status? Does justification transition from the work of Christ to the work of the Spirit to facilitate its present and final stages, or is there one stage of justification that rests on the imputed righteousness of Christ alone? Such questions are not merely for historians but for the church today, as the passing of time, 
whether from the thirteenth or sixteenth century has not slowed debate over these questions. Rather than decide these issues in isolation from the historic church, we should seek to retrieve earlier discussions so we can enrich our own doctrinal reflections.

\section{Bibliography}

Aquinas T (2012) Commentary on the Letter of Saint Paul to the Romans. Lander,

WY: The Aquinas Institute for the Study of Sacred Doctrine.

Aquinas T (1948) Summa Theologica. Allen, TX: Christian Classics.

Aquinas T (1974) Summa Theologiae, vol. 31, Faith, trans. T. C. O'Brien.

(London: Eyre and Spottiswoode.

Braaten CE and Jenson RW, eds (1998) Union with Christ: The New Finnish Interpretation of Luther. Grand Rapids: Eerdmans.

Calvin J (1957) Institutes of the Christian Religion, trans. Henry Beveridge. Grand Rapids: Eerdmans.

Canlis J (2010) Calvin's Ladder: A Spiritual Theology of Ascent and Ascension. Grand Rapids: Eerdmans.

Donnelly JP (1976) Italian Influences on the Development of Calvinist Scholasticism. Sixteenth Century Journal 7(1): 81-101.

Evans WB (2009) Imputation and Impartation: Union with Christ in American Reformed Theology. Eugene, OR: Paternoster.

Farthing JL (1994) Christ and the Eschaton: The Reformed Eschatology of Jerome Zanchi, in Later Calvinism: International Perspectives, ed. W. Fred Graham. Kirksville: Sixteenth Century Journal Publishers, pp. 332-54.

Farthing JL (1993) De coniugio spirituali: Jerome Zanchi on Ephesians 5:2233. Sixteenth Century Journal 24(3): 621-52.

Fesko JV (2012) Beyond Calvin: Union with Christ and Justification in Early Modern Reformed Theology (1517-1700). Göttingen: Vandenhoeck and Ruprecht.

Hampson D (2004) Christian Contradictions: The Structures of Lutheran and Catholic Thought. Cambridge: Cambridge University Press.

Johnson MP (2013) One with Christ: An Evangelical Theology of Salvation. Wheaton, IL: Crossway.

Lewis CS (1970) God in the Dock: Essays on Theology and Ethics, ed. Walter Hooper. Grand Rapids: Eerdmans.

Lombard P (2007) Sentences, 4 vols., trans. Giulio Silano. Toronto: Pontifical Institute of Medieval Studies.

McGrath A (2005) Iustitia Dei: A History of the Christian Doctrine of Justification, 3rd ed. Cambridge: Cambridge University Press.

Muller RA (2012) Calvin and the Reformed Tradition: On the Work of Christ and the Order of Salvation. Grand Rapids: Baker. 
Muller RA (1988) Christ and the Decree: Christology and Predestination in Reformed Theology from Calvin to Perkins. Grand Rapids: Baker.

Partee C (2008) The Theology of John Calvin. Louisville, KY: Westminster John Knox Press.

Porter J (2005) Right Reason and the Love of God: The Parameters of Aquinas' Moral Theology, in The Theology of Thomas Aquinas, eds. Rik van Nieuwenhove and Joseph Wawrykow. Notre Dame: University of Notre Dame Press, pp. 167-91.

Raith II C (2014) Aquinas and Calvin on Romans: God's Justification and Our Participation. Oxford: Oxford University Press.

Spezzano D (2015) The Glory of God's Grace: Deification According to St. Thomas Aquinas. Ave Maria, FL: Sapientia Press.

Torrell J-P (2003) Saint Thomas Aquinas, 2 vols., trans. Robert Royal. Washington: Catholic University of America Press, 2003.

Vanhoozer K (2011) Wrighting the Wrongs of the Reformation? The State of Union with Christ in St. Paul and Protestant Soteriology, in Jesus, Paul, and the People of God: A Theological Dialogue with N. T. Wright, eds. Nicholas Perrin and Richard B. Hays. Downers Grove, IL: InterVarsity Press, pp. 235-58.

Webster J (2007) Theologies of Retrieval, in The Oxford Handbook Systematic Theology, eds. John Webster, Kathryn Tanner, and Iain Torrance. Oxford: Oxford University Press, pp. 583-99.

Williams AN (1997) Mystical Theology Redux: The Pattern of Aquinas' Summa Theologiae. Modern Theology 13(1): 53-74.

Wright NT (2011) Justification: Yesterday, Today, and Forever. Journal of the Evangelical Theological Society 54(1): 49-63.

Wright NT (2013) Paul and the Faithfulness of God, vol. 2. Minneapolis: Fortress, 2013.

Wright NT (2002) Romans. Nashville: Abingdon Press.

Wright NT (2008) Surprised by Hope: Rethinking Heaven, the Resurrection, and the Mission of the Church. San Francisco: Harper One.

Zanchi G (1888) Commentarius in Epistolam Sancti Pauli Ad Ephesos, 2 vols., ed. A. H. Hartog, Bibliotheca Reformata, vol. 5. Amsterdam.

Zanchi G (2007) De Religione Christiana Fides-Confession of Christian Religion, 2 vols., eds. Luca Baschera and Christian Moser. Leiden: Brill.

Zanchi G (1592) An Excellent and Learned Treatise of the Spiritual Marriage between Christ and the Church. Cambridge: John Legate. 